УдК 342.12

\author{
О. С. Бурлака
}

\title{
ДЕРЖАВНІ СОЦІАЛЬНІ ПІЛЬГИ В СИСТЕМІ СОЦІАЛЬНОГО ЗАХИСТУ СІМ'Ї, ДИТИНСТВА, МАТЕРИНСТВА ТА БАТЬКІВСТВА В УКРАЇНI
}

Актуальність теми. В українському суспільстві питання ефективності надання пільг та визначення кола осіб, які належать до пільгових категорій громадян, дискутується з початку 90-х рр. минулого століття. 3 одного боку, унаслідок обмежених матеріально-фінансових можливостей держава виявилась неспроможною забезпечити фінансування всіх задекларованих і закріплених у законодавстві пільг, а з іншого - перманентно збільшується кількість категорій осіб, які претендують на пільги, а також кількість самих осіб [1].

В Україні за багато років створилася складна й розгалужена система пільг. Їі регулюють 46 нормативно-правових актів, відповідно до яких держава має зобов'язання щодо надання 156 видів соціальних пільг, гарантій і компенсацій 230 категоріям населення, що складає близько $43 \%$ населення [2], проте більшість з цих пільг отримують ті категорії громадян, які менш за всіх їх потребують. Тому система встановлення соціальних пільг для вразливих категорій громадян, у тому числі й для сімей з дітьми, багатодітних, неповних і малозабезпечених сімей, дітей-сиріт та дітей, позбавлених батьківського піклування, інвалідів з дитинства та дітей-інвалідів $€$ непрозорою та недосконалою.

Стан наукового дослідження. Теоретичні та практичні аспекти соціальних пільг досліджували у своїх працях такі вчені, як Н.Б. Болотіна, К.В. Бориченко, Е.Е. Мачульська, К.Ю. Мельник, О.М. Потопахіна, С.М. Прилипко, С.М. Синчук, I.M. Сирота, Б.І. Сташків, Е.Г. Тучкова, Н.А. Чередніченко, М.В. Чічкань, О.Г. Чутчева, В.Ш. Шайхатдинов, I.C. Ярошенко та ін. Проте, незважаючи на значну кількість наукових праць, у сфері соціального забезпечення комплексного дослідження соціальних пільг, які встановлюються для сімей з дітьми, багатодітних, неповних і малозабезпечених сімей, дітей-сиріт і дітей, позбавлених батьківського піклування, інвалідів з дитинства та дітей-інвалідів, не проводилось. 
Мета статті полягає у з'ясуванні сутності державних соціальних пільг, які встановлюються для сімей 3 дітьми, багатодітних, неповних і малозабезпечених сімей, дітей-сиріт і дітей, позбавлених батьківського піклування, інвалідів з дитинства та дітей-інвалідів, виокремлення їх основних ознак та визначення відповідної системи таких пільг.

Виклад основного матеріалу. Необхідно спочатку звернутись до теоретичних надбань науки соціального забезпечення та з'ясувати сутність поняття «пільги». Так, у юридичній енциклопедії за редакцією Ю.С. Шемчушенка пільги розуміються як встановлені законодавством переваги, що надаються особі (чи групі осіб) порівняно з іншими особами; можуть полягати у звільненні тих чи інших осіб від відповідних обов'язків або наділенні їх додатковими гарантіями [3].

Державна соціальна пільга (за законодавством Республіки Білорусі) це передбачені законодавством переваги, повне чи часткове звільнення від виконання обов'язків або полегшення умов їх виконання у зв'язку з особливим соціально-правовим статусом особи або особливостями їх професійної діяльності [4]. Під соціальними пільгами у праві соціального забезпечення Г.Г. Пашкова розуміє юридичний засіб створення сприятливого режиму для громадян, які знаходяться у складній життєвій ситуації, що виражається у повному чи додатковому звільненні від виконання певних обов'язків [5, с. 6]. Так, соціальні пільги є одним із інструментів (засобів) подолання складних життєвих обставин.

Забезпечення пільгами, за визначенням А.А. Казанчана, - це вид соціального забезпечення, що передбачає покращення матеріального становища непрацездатних громадян або у зв'язку зі збільшенням доходів (заробітку, пенсій, допомог, стипендій), або у зв'язку зі зменшенням їх витрат (на медичну допомогу та лікування, санаторно-курортне лікування, ремонт житла, проїзд в транспорті, встановлення телефону тощо) [6].

На думку М.Л. Захарова й Е.Г. Тучкової, соціальні пільги відрізняються тим, що їх надання зазвичай не пов'язане 3 діяльністю спеціальних, особливо створених соціальних служб (різних соціальних установ, організацій); вони надаються звичайними службами - комунальними, торговельними й іншими організаціями та органами. Крім того, для здійснення права на соціальні пільги часто не потрібно рішення зобов'язаної сторони. Тобто громадяни самі здійснюють своє суб'єктивне право на пільги (безкоштовний проїзд на міському транспорті, знижена оплата комунальних послуг тощо) [7, с. 56].

У свою чергу, П.Д. Пилипенко під соціальними пільгами пропонує розуміти законодавче звільнення (повне або часткове) особи від виконання нею свого обов'язку або надання ӥй додаткових прав після настання соціального ризику чи за наявності у такої особи значних заслуг перед державою, пов'язаних з певними публічними подіями [8, с. 438].

Таким чином, під соціальними пільгами в системі соціального захисту сім'і, дитинства, материнства та батьківства слід розуміти часткове або повне звільнення сімей з дітьми, багатодітних, неповних і малозабезпе- 
чених сімей, дітей-сиріт і дітей, позбавлених батьківського піклування, інвалідів з дитинства та дітей-інвалідів від виконання певного обов'язку у відповідній сфері (житлово-комунальній, транспортній, соціально-побутовій тощо), а також надання додаткових прав з метою подолання чи пом'якшення відповідних соціальних ризиків (малозабезпеченість, бідність, сирітство, інвалідність, багатодітність тощо).

Серед ознак соціальних пільг виділяють такі:

1) пільги спрямовуються на більш повне задоволення інтересів суб'єктів, полегшення умов їх життєдіяльності (соціальна пільга надається 3 метою зменшити обсяг обов'язкових, пов'язаних із щоденними турботами, матеріальних витрат сім'ї як члена суспільства, а також соціально сприяти фізичним особам, які, зважаючи на особливий правовий статус, потребують допомоги суспільства у реалізації конституційних прав);

2) соціальні пільги задовольняють потреби осіб, які зазнали впливу соціального ризику;

3) пільги є своєрідним відхиленням від єдиних положень нормативного характеру та способом юридичної диференціації прав громадян, елементом їх спеціального правового статусу, механізмом доповнення основних прав суб'єкта специфічними можливостями юридичного характеру;

4) особливим є зміст соціальної пільги як виду соціального забезпечення, що дає змогу відмежувати ії від інших видів соціального забезпечення (зміст соціальної пільги характеризують правоможності, якими наділена особа - суб'єкт права на соціальну пільгу: переважне або додаткове право на отримання необхідного для особи соціального блага; звільнення від обов'язку вчиняти певні діï);

5) соціальні пільги мають різні форми, які залежать від об’єкта (у вигляді платежу чи послуги), у сфері якого надається соціальна пільга (грошова форма - зменшення грошових виплат за житлово-комунальні послуги тощо; безготівкова - звільнення від оплати обов'язкових платежів; послуга - переважне право на отримання гуртожитку, на зарахування у ВНЗ тощо);

6) для механізму надання соціальних пільг характерна відсутність зобов'язаного компетентного органу спеціальної правосуб'єктності, тобто забезпечення соціальними пільгами не пов'язане з діяльністю спеціально створених, відокремлених державних органів чи організацій, соціальних служб [9, с. 302-305].

До характерних рис соціальних пільг Н.М. Вапнярчук відносить такі:

а) пільги є організаційно-правовою формою соціального забезпечення;

б) пільги адресовані громадянам, які мають особливі заслуги перед державою або суспільством, перебувають в особливому статусі - за станом здоров'я, віком тощо;

в) пільги визначені законодавством, але можуть установлюватися індивідуально на окремих підприємствах, установах організаціях;

г) основна мета - поліпшити становище окремих категорій населення, звільнити повністю або частково від виконання обов'язку (наприклад, зниження плати за послуги) [10, с. 100]. 
Також необхідно звернути увагу на систему пільг, що склалася в Україні, яку можна класифікувати в різний спосіб. Зокрема, можлива класифікація за такими критеріями:

1) за принциповою ознакою отримувачів пільг: а) пільги за особливі заслуги перед Батьківщиною. За цією ознакою право на пільги мають Герої України, Герої Радянського Союзу, Герої соціалістичної праці, учасники бойових дій, інваліди війни, ліквідатори наслідків катастрофи на ЧАЕС; б) пільги за соціальною ознакою. Ці пільги можна розглядати як підтримку осіб у зв'язку з віком, станом здоров'я, соціальним станом, недостатнім забезпеченням засобами існування. За соціальною ознакою отримують пільги учасники війни та прирівняні до них особи, сім’ї загиблих (або тих, які пропали безвісти) учасників бойових дій, військовослужбовців, партизанів тощо, потерпілі внаслідок Чорнобильської катастрофи, ветерани праці, військової служби та внутрішніх справ, військовослужбовці, які стали інвалідами внаслідок проходження військової служби, реабілітовані особи, які стали інвалідами внаслідок репресій або $є$ пенсіонерами, а також пенсіонери та інваліди; в) пільги за професійною ознакою. Цей вид пільг покликаний заохочувати працівників складних і суспільно значущих професій, а також залучати працівників у сільську місцевість. До пільговиків за професійною (службовою) ознакою належать працівники міліції, суду, прокуратури, військовослужбовці, працівники державної пожежної охорони, державні службовці; педагогічні, медичні та фармацевтичні працівники, журналісти, які проживають у сільській місцевості, тощо;

2) в залежності від можливості вартісної оцінки: а) ті, вартість яких може бути виміряна (пільгова оплата таких товарів або послуг: житло, комунальні послуги, електроенергія, паливо; проїзд міським, приміським і міжміським транспортом; встановлення телефону та користування ним; санаторно-курортне лікування; придбання медикаментів; зубопротезування та забезпечення протезами; придбання (будівництво) житла; б) ті, які важко оцінити в грошовому вимірі - це пільги, які надають право пільговику отримувати певні послуги або товари позачергово (першочергове обслуговування в лікарнях чи аптеках, забезпечення товарами підвищеного попиту, позаконкурсний вступ до вищих навчальних закладів тощо);

3) в залежності від множинності їх використання: а) разові (отримання пільгового кредиту на будівництво/придбання житла, безплатний капітальний ремонт житла, отримання автомобіля); б) багаторазові (пільги 3 оплати житлово-комунальних послуг, на проїзд у міському, приміському, місцевому та міжміському транспорті, користування телефоном і сигналізацією, санаторно-курортне лікування (або компенсація), зубопротезування, купівля медикаментів тощо);

4) в залежності від суб'єкта отримання: а) індивідуальні (пільги на користування транспортом, отримання медикаментів, зубопротезування); б) які поширюються на членів сім'ї пільговика (житлово-комунальні (пільгове забезпечення паливом), пільги на користування телефоном, безплатний капремонт тощо) [11, с. 8]. 
За змістом усі соціальні пільги можна поділити на:

1) житлово-комунальні (звільнення або зменшення плати за житло, комунальні послуги; першочергове або позачергове забезпечення житлом осіб, які потребують поліпшення житлових умов; надання бюджетних кредитів та позик на індивідуальне житлове будівництво; безкоштовний ремонт житлових будинків (квартир), що перебувають у їх власності, або компенсація витрат на його виконання власними силами відповідно до «Положення про систему технічного обслуговування, ремонту, реконструкції; безоплатна приватизація житла незалежно від розміру загальної площі);

2) медико-реабілітаційні (безоплатне або пільгове придбання ліків; безоплатне або пільгове санаторно-курортне лікування та виплата компенсації за невикористане право на пільгове санаторно-курортне лікування);

3) транспортні (право безкоштовного проїзду всіма видами пасажирського міського (комунального) та приміського транспорту);

4) соціально-побутові (право на безоплатне або пільгове встановлення телефонів; безоплатне або пільгове користування телефоном);

5) пенсійні (надбавки до трудової чи соціальної пенсії; зменшена вимога щодо необхідного трудового чи страхового стажу особи);

6) соціально-трудові (право на позаконкурсне зарахування до вищих навчальних закладів за умови одержання позитивних оцінок; право позачергового працевлаштування за спеціальністю; переважне право на залишення на роботі при скороченні чисельності або штату та на працевлаштування в разі ліквідації підприємства; підвищений розмір допомоги в разі тимчасової непрацездатності; використання щорічної відпустки у зручний час тощо) [12].

Відповідно до положень Закону України «Про охорону дитинства» від 26.04 .2001 р. № 2402-III, а саме ст. 13, багатодітним сім’ям надаються такі пільги:

1) 50-відсоткова знижка плати за користування житлом (квартирна плата) у межах норм, передбачених чинним законодавством (21 кв. метр загальної площі житла на кожного члена сім’і, який постійно проживає в жилому приміщенні (будинку), і додатково 10,5 кв. метра на сім'ю);

2) 50-відсоткова знижка плати за користування комунальними послугами (газопостачання, електропостачання та інші послуги) і вартості скрапленого балонного газу для побутових потреб у межах норм, визначених законодавством.

3) 50-відсоткова знижка вартості палива, у тому числі рідкого, у межах норм, визначених законодавством, якщо відповідні будинки не мають центрального опалення;

4) позачергове встановлення квартирних телефонів. Абонентна плата за користування квартирним телефоном встановлюється у розмірі 50 відсотків від затверджених тарифів.

Дітям з багатодітних сімей надаються такі пільги:

1) безоплатне одержання ліків за рецептами лікарів; 
2) щорічне медичне обстеження та диспансеризація в державних і комунальних закладах охорони здоров'я із залученням необхідних спеціалістів, а також компенсація витрат на зубопротезування;

3) першочергове обслуговування в лікувально-профілактичних закладах, аптеках і першочергова госпіталізація;

4) безоплатний проїзд усіма видами міського пасажирського транспорту (крім таксі), автомобільним транспортом загального користування в сільській місцевості, а також залізничним і водним транспортом приміського сполучення та автобусами приміських і міжміських маршрутів, у тому числі внутрішньорайонних, внутрішньо- та міжобласних незалежно від відстані та місця проживання;

5) безоплатне одержання послуг з оздоровлення та відпочинку відповідно до Закону України «Про оздоровлення та відпочинок дітей» [13].

Висновок. Аналізуючи чинне законодавство у сфері соціального захисту сім'і, дитинства, материнства та батьківства, необхідно виокремити такі соціальні пільги, які встановлюються для багатодітних, неповних, малозабезпечених сімей, дітей-сиріт і дітей позбавлених батьківського піклування, інвалідів з дитинства та дітей-інвалідів:

1) надання пільгових кредитів;

2) надання 50-відсоткової знижки на користування житлом, комунальними послугами, вартість палива;

3) пільги в оподаткуванні;

4) позачергове отримання квартир або садибних будинків із соціального фонду;

5) пільговий проїзд усіма видами міського пасажирського транспорту (крім таксі), автобусами приміських і міжміських маршрутів тощо;

6) надання адресної безготівкової субсидії;

7) безоплатне харчування в державних та комунальних дошкільних, загальноосвітніх навчальних закладах і шкільна форма;

8) пільги щодо влаштування до вищих навчальних закладів дітей-інвалідів, дітей із малозабезпечених сімей, дітей-сиріт і дітей, позбавлених батьківського піклування;

9) пільги у сфері охорони здоров'я (безкоштовне оздоровлення та відпочинок, одержання ліків за рецептами та ін.) тощо.

Таким чином, аналізуючи характер зазначених пільг, можемо поділити ïх на відповідні групи (види), а саме пільги на житлово-комунальні послуги, пільги у сфері транспортного обслуговування, соціально-побутові пільги, медико-соціальні пільги.

\section{Література}

1. Кравченко М.В. Основні підходи до реформування системи пільг в Україні / М.В. Кравченко // Державне управління та місцеве самоврядування. - Дніпропетровськ : ДРІДУ НАДУ, 2010. - № 3 (6). - [Електронний ресурс]. - Режим доступу : http:/ / www.dbuapa.dp.ua/vidav nictvo/2010/2010_03(6)/10kmvspu.pdf.

2. Звіт про науково-дослідну роботу «Моніторинг досвіду країн Європи, США, країн пострадянського простору, включаючи прибалтійські країни, в частині надання пільг окремим категоріям громадян» / С.В. Мельник, М.К. Гаврицька, I.M. Овчарова / / Державна установа 
науково-дослідний інститут соціально-трудових відносин. - Луганськ, 2011. - [Електронний pecypc]. - Режим доступу : http://www.mlsp.kmu.gov.ua\%2Fdocument-\%2F87154\%2FZvit_ monit_dosvid_pilg.doc.

3. Юридична енциклопедія : в 6 т. / редкол. : Ю.С. Шемчушенко та ін. - К. : Укр. енцикл., 1998- . - Т. 4 : Н-П. - 2002. - 720 с.

4. О государственных социальных льготах, правах и гарантиях для отдельных категорий граждан : Закон Республики Беларусь от 14 июня 2007 г. № 239 // Нац. Реестр правовых актов Республики Беларусь. - 2007. - №147.

5. Пашкова Г.Г. Льготы в праве социального обеспечения : автореф. дис. ... канд. юрид. наук / Г.Г. Пашкова. - Томск, 2004. - 27 с.

6. Казанчан А.А. Види соціального забезпечення в Україні: проблемні питання / А.А. Казанчан / / Вісник Запорізького юридичного інституту, Дніпропетровського державного університету внутрішніх справ. - 2010. - № 3 - С. 11-20.

7. Захаров М.Л. Право социального обеспечения России : [учебник] / М.Л. Захаров, Э.Г. Тучкова. - 2-е изд., испр. и перераб. - М. : БЕК, 2002. - 560 с.

8. Право соціального забезпечення : [підруч. для студ. вищ. навч. закл.] / [П.Д. Пилипенко, В.Я. Буряк, С.М. Синчук та ін.] ; за ред. П.Д. Пилипенка. - 2-ге вид., перероб. і допов. - К. : Iн Юре, 2008. - 504 c.

9. Синчук С.М. Правові ознаки соціальних пільг у сфері соціального забезпечення / С.М. Синчук // Держава і право. - 2012. - Вип. - 56. - С. 301-306.

10. Вапнярчук Н.M. Пільга як одна з форм системи соціального забезпечення / Н.М. Вапнярчук / / Право і суспільство. - 2015. - № 3. - Ч. 3. - С. 97-101.

11. Реформування системи пільг. Проект «Позиція громадськості щодо урядових пріоритетів та інституалізація урядових консультацій з громадськістю у процесі формування державної політики в Україні / Є.В. Ахтирко, Л.А. Котусенко та ін. - К., 2004. - 81 с.

12. Хаймадюк О.А. Пільги ветеранам війни та особам, прирівняним до них / О.А. Хаймадюк / / Довідник кадровика. - 2007. - № 4. - С. 12-13.

13. Про охорону дитинства : Закон України від 26.04.2001 р. № 2402-III / / Відомості Верховної Ради України. 2001. - № 30. - Ст. 142.

\section{Ано т а ц і}

Бурлака О. С. Державні соціальні пільги в системі соціального захисту сім'ї, дитинства, материнства та батьківства в Україні. - Стаття.

У статті визначено сутність поняття «соціальні пільги в системі соціального захисту сім'ї, дитинства, материнства та батьківства», визначено основні ознаки соціальних пільг, здійснено їх класифікацію. Також автор виділив систему пільг, які встановлюються для сімей з дітьми, багатодітних, неповних і малозабезпечених сімей, дітей-сиріт і дітей, позбавлених батьківського піклування, інвалідів з дитинства та дітей-інвалідів.

Ключові слова: соціальні пільги, соціальний захист, дитинство, материнство, батьківство.

\section{Анн о т а ция}

Бурлака О. С. Государственные социальные льготы в системе социальной защиты семьи, детства, материнства и отцовства в Украине. - Статья.

В статье определена сущность понятия «социальные льготы в системе социальной защиты семьи, детства, материнства и отцовства», определены основные признаки социальных льгот, осуществлена их классификация. Также автором выделена система льгот, которые устанавливаются для семей с детьми, многодетных, неполных и малообеспеченных семей, детей-сирот и детей, лишенных родительской опеки, инвалидов с детства и детей-инвалидов.

Ключевые слова: социальные льготы, социальная защита, детство, материнство, отцовство. 


\section{S u m m a r y}

Burlaka O. S. State social benefits in the social security system, family, childhood, motherhood and fatherhood in Ukraine. - Article.

The article defines the essence of the concept of "social benefits in the social security system, family, childhood, motherhood and fatherhood", defines the main features of social benefits, their classification. The author also highlighted the benefits system, which are set for families with children, large families, single-parent and low-income families, orphans and children deprived of parental care, disabled children and children with disabilities.

Key words: social benefits, social security, childhood, motherhood, fatherhood. 